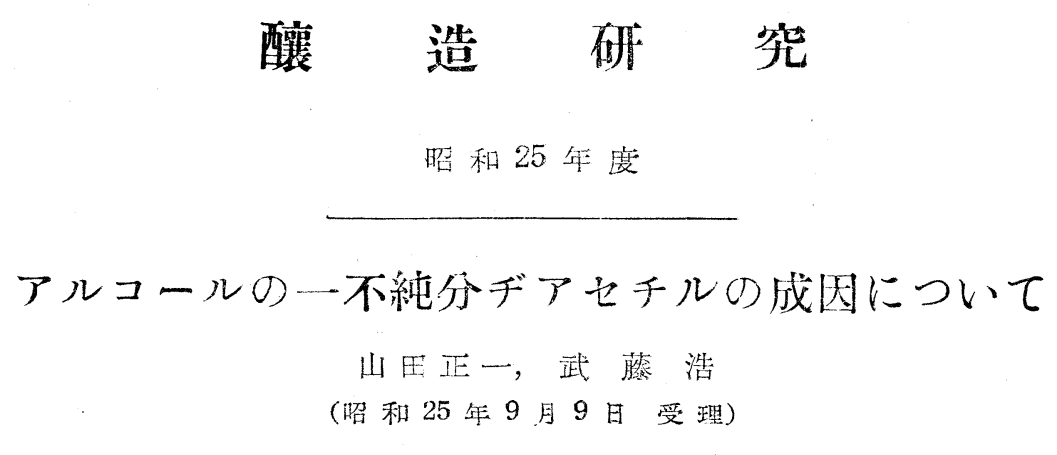

On the occurrence of diacetyl as an impurity of alcohol

By

Masakazu Yamada and Hiroshi Mutō

飲料アルコールのー不純成分としてデア七チルの存在する事忙近比注澺された處であるが此の物は酒類

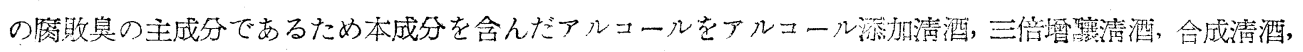
ウィスキー，甘昧葡萄酒等の原料とする時何れも不快悬を示すものである。幸此の種のアルコールは過酸

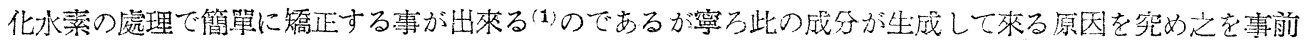
に防止する事が先決問題である。

先づ第一に清酒の例で見ると其の中には痕跡のヂア七チルを含むが火落すると急速に壻加し惡臭を示す ようになる。(2)何れも細菌の作用によるものと想像される。アルュールもろみについては或は蒸溜中の機

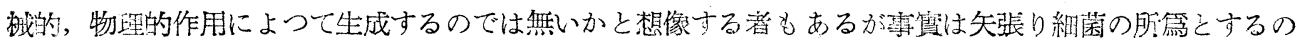

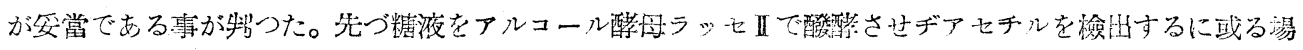

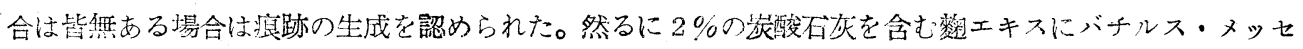
ンテリクスを繁殖させると其の溜液では多量のデアセチ几を檢出する事が出來た。(3)訒諭此の際一筧多量

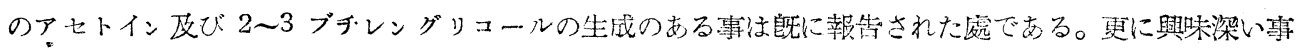
は紑豆に於ても其の水溶液を蒸溜すると少量のデア七チルの存忹を認められる。尤も其の故に此の成分が 納豆の香りの主成分である等と云う譯では無い。

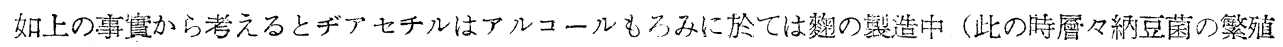

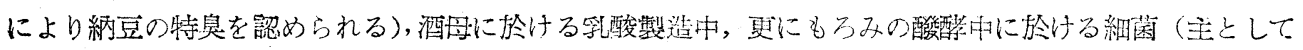
乳酸菌）の污染繁殖により生成する機會がある。アミロ法に於でももろる㭙代に必ず細菌の增殖を見るも のとすれば夫が原因となるものと考えられる。從つて此の物の生成を防止する簏には必要な細菌の堌殖は

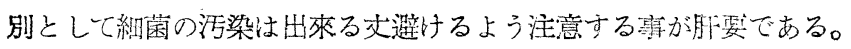

\title{
賽驗
}

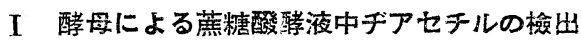

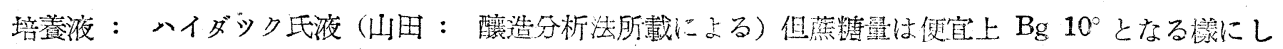
た。 $\mathrm{pH}$ は 6.0 である。

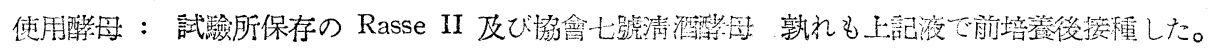

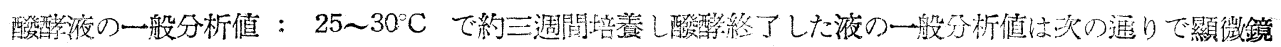

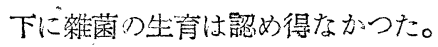

$$
\text { ボーリング アルニール 酸 } \mathrm{cc} \text { 度 殘 } \% \text { 糖 }
$$

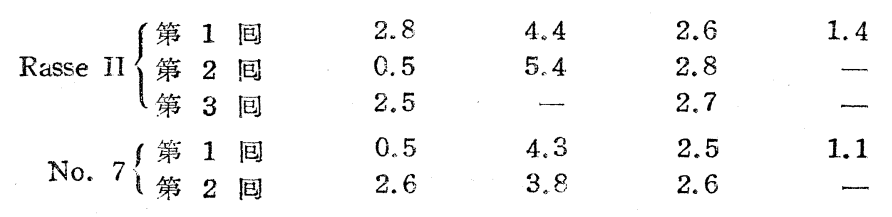




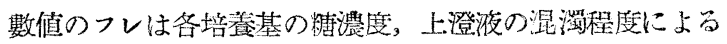

ヂアセチルの檢出：上記醱禁液の上澄を蒸溜し溜液に就てVan-Niel 氏法（前揭分析法記載）により 檢出站に定量を行つた。看ち

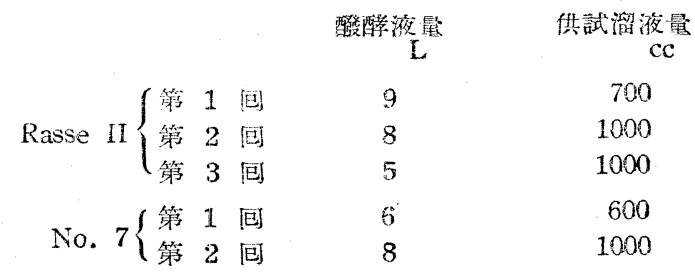

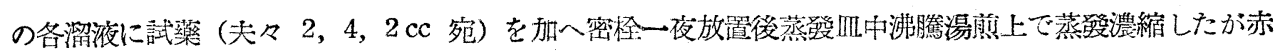
色針狀のニッゥルヂメチルグリオキシムの結晶は鏡下にても認められなかつた但 Rase II 第 2 他に於て 一度だけ蒸發且壁面に淡く桃色に析出した。この檢出法がアルュールの存在により析出量を減ずることは

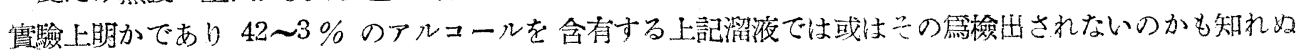
が勍れにせよこの檢出では殆んぞデアセチルの生成を認めなかつた。

\section{II 納豆蒐の粷エキス培盖液中ヂアセチルの生成}

培養液 : $2 \%$ 沈炭添加雾エキス $(\mathrm{Bg} 10)$

使用菌： 當所保存のバチルス・ナットーを上記液に前培養して接種した。

ギアセデルの生成量：30〜32 $\mathrm{C} 20$ 日後培養液の上澄 $3 \mathrm{~L}$ を蒸溜し溜液 $1 \mathrm{~L}$ をる每に水 $1 \mathrm{~L}$ を加え $5 \mathrm{~L}$ の溜液を得た。これを I 同樣に處理し析出した結晶は一旦グラスフィルターで滤別し更に濾液は濃縮

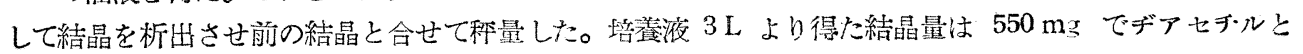
して $330 \mathrm{mg}$ 培養液中 $0.011 \%$ 存した事になる。

\section{III納豆中ヂアセチルの檢出}

a) 自家製納豆 (上記バチルスナット菌使用) $1 \mathrm{~kg}$ を水 $2,1,1 \mathrm{~L}$ と逐次水洗し洗液を合して稀硫酸 で微酸性迄中和後, 蒸溜し溜液 $100 \mathrm{cc}$ に就て同椂の檢出を試みた結果は濃縮により赤色を是しニッヶル ヂメチルグリオキシム結晶の生成を認めた。この量は意外に少かつたが

b) 目家製又は市販納豆 $100 \mathrm{gr}$ に水少量と稀硫酸 數 ce とを加一水蒸氮蒸溜を行い溜液 $500 \mathrm{cc}$ をと

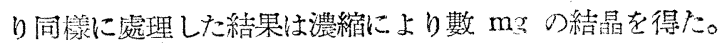

\section{Strmmary}

In Japanese sake the existence of diacetyl is a remarkable feature of its most common putrifaction so-called 'Hi-o-chi'. By this reason alcohol for beverage use is required absolutely free from diacetyl in this country. The authers defined in this experiment the occurrence of this constituent is not induced by the normal action of yeast but the certain bacterial contamination and appointted that the careful preparation of the more microbiologically pure mash is essential for decreasing diacetyl content of the product.

\section{引用交}

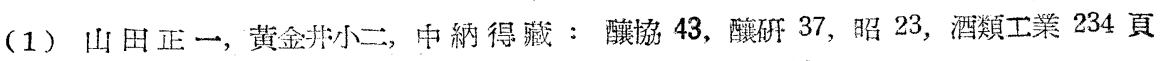

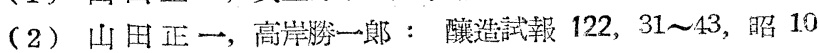

（3）山田正一, 杉原一男：釀造試報 127, 27 32, 昭 13 